\title{
Screening of Effective Media for Black Soldier Fly Larvae Used in Food Waste Treatment
}

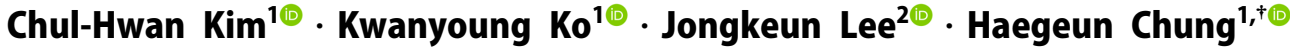 \\ 'Department of Environmental Engineering, Konkuk University \\ ${ }^{2}$ Department of Civil \& Environmental Engineering, Konkuk University
}

(Received August 27, 2020; Revised September 29, 2020; Accepted October 5, 2020)

Objectives: Black soldier fly larvae (BSFL) are organisms that effectively decompose various types of organic waste including food waste, and food waste treatment using BSFL is attracting attention as a sustainable waste treatment method. However, food waste discharged from Korea has a wide variety of properties, and its high salt concentration limits its treatment by BSFL. Therefore, to increase the efficiency of food waste treatment using BSFL, it is necessary to increase the quality of food waste as a production medium for BSFL. In this study, the ratio of protein and fat was adjusted by adding bean sprouts and wheat brans to food wastes treated at high temperature under vacuum, and whether such medium is suitable for rearing BSFL was investigated.

Methods: To improve the medium, the ratio of protein and fat was adjusted to approximately $2: 1$ by adding bean sprouts and bran residue to food waste. Subsequently, the growth and development rate of BSFL reared on chicken feed, food waste, food waste + bean sprouts, food waste + wheat bran were measured. Also, the decomposition rate of each medium was analyzed.

Results and Discussion: The growth rate of BSFL grown on food waste + wheat bran medium was similar to that of BSFL reared on chicken feed. The speed of development at day 7 was also the fastest for BSFL reared with food waste + wheat bran medium and chicken feed. These results suggest that the mixed medium to which wheat bran has been added to food waste has the potential to be used as a commercial medium for BSFL production. The survival rate of BSFL was $89 \%$ or higher in all media.

Conclusions: When food waste was used alone, BSFL development was poor compared to that in media combined with agricultural by-products such as bean sprouts and wheat bran. Therefore, to use food waste as a rearing medium of BSFL, it is necessary to adjust the ratio of protein and fat by adding various agricultural by-products and reduce salinity. For the improvement of food waste treatment technology using BSFL, mass rearing of useful insects such as BSFL, and promotion of the use of agricultural by-products, additional research is needed to optimize the composition of rearing medium based on food waste.

Keywords : Black Soldier Fly, Food Waste, Sustainability, Useful Insects, Culture Medium

The Korean text of this paper can be translated into multiple languages on the website of http:/jksee.or.kr through Google Translator. 


\title{
연구논문
}

\section{음식물 폐기물에 기반한 동애등에 생장 배지 선별}

\author{
김철환 $^{1 \oplus} \cdot$ 고관영 ${ }^{1 \oplus} \cdot$ 이종근 $^{2 \oplus} \cdot$ 정혜근 $^{1+\oplus}$ \\ 1건국대학교 환경공학과 \\ 2건국대학교 사회환경공학부
}

목적 : 동애등에는 음식물 폐기물을 포함한 다양한 종류의 유기성 폐기물을 효과적으로 분해하는 생물로 동애등에 를 이용한 음식물 폐기물 처리는 친환경적인 폐기물 처리방법으로 주목을 받고 있다. 그러나 한국에서 배출되는 음식물 폐기물은 구성 성분과 성상이 매우 다양하며 염분농도가 높아 동애등에가 처리하는 데에 제약이 있다. 그 러므로 국내에서 동애등에를 이용한 음식물 폐기물 처리의 효율성을 높이기 위해서는 음식물 폐기물 내 추가적인 기질을 더하여 단백질과 지방의 비율을 조정하고 염분을 낮추는 등 동애등에 생산 배지로써의 음식물 폐기물의 질 을 높일 필요가 있다. 본 연구에서는 진공 상태에서 고온 처리한 음식물 폐기물에 각각 콩나물과 밀기울 찌꺼기를 추가하여 단백질과 지방의 비율을 조정하였고 이와 같은 배지가 동애등에 사육에 적합한지 밝히고자 하였다.

방법: 배지의 개량을 위해 음식물 폐기물에 콩나물과 밀기울 찌꺼기를 추가하여 단백질과 지방의 비율을 약 $2: 1$ 로 조정하였다. 그 후 닭 사료, 음식물 폐기물, 음식물 폐기물+콩나물, 음식물 폐기물+밀기울 배지에서 7일 동안 자란 동애등에의 성장률, 발달 속도 및 배지 분해율을 측정하였다.

결과 및 토의: 닭 사료, 음식물 폐기물, 음식물 폐기물+콩나물 그리고 음식물 폐기물+밀기울 배지에서 동애등에를 사육한 결과 음식물+밀기울 배지에서 자란 동애등에의 성장률은 대조구인 닭 사료에서 자란 동애등에와 비슷하였 다. 발달 속도 또한 음식물+밀기울 배지와 닭 사료에서 자란 동애등에가 7일로 가장 빨랐다. 이러한 결과는 밀기울 을 추가한 배합 배지가 동애등에 생산을 위한 실용화 배지로 쓰일 수 있는 가능성이 있음을 시사한다. 생존율은 배지의 종류에 따라 차이가 없이 모든 배지에서 $89 \%$ 이상이었다.

결론 : 음식물 폐기물을 단독으로 사용했을 때는 콩나물, 밀기울 등의 농업부산물과 배합했을 때에 비해 동애등에 생장이 저조한 결과를 보였다. 따라서 음식물 폐기물을 동애등에 사육 배지로 이용하기 위해서는 다양한 농업 부 산물을 추가해서 단백질과 지방의 비율을 조정하고 염분을 감소시킬 필요가 있는 것으로 보인다. 동애등에를 이용 한 음식물 폐기물 처리 기술의 향상, 동애등에와 같은 유용 곤충 대량 사육, 농업부산물의 활용 분야 확장을 위해 서는 음식물 폐기물에 기반한 사육 배지의 조성을 최적화하는 연구가 추가적으로 필요할 것으로 사료된다.

주제어 : 동애등에, 음식물 폐기물, 지속가능성, 유용 곤충, 사육 배지

\section{1. 서 론}

음식물 폐기물은 생활 수준의 향상과 인구 증가로 인해 그 발생량이 증가하는 추세이다. FAO (Food and Agriculture Organization)는 음식물 폐기물을 일반적으로 소매 및 소비 단계에서 폐기되는 음식으로 정의하고 있으며, 한국의 경우 음식물과 식재료를 생산, 유통, 가공, 조리, 저장, 소비하는 과정에서 발생하거나 버려지는 폐기물로 정의하고 있다. ${ }^{1)}$ 이러한 음식물 폐기물은 매년 전세계적으로 발생하는 21 억 톤 이상의 도시 고형 폐기물 중 25-45 wt.\%에 해당하며, 음 식물 폐기물의 증가는 전세계적으로 식량 시스템의 불균형
을 초래하고 적절하게 처리되지 않을 경우 인간의 건강, 생 물 다양성 및 생태계에 악영향을 미칠 수 있다.2) 이에 따라 음식물 폐기물을 효율적으로 처리하는 기술이 요구되는데 대표적인 기술로는 호기성 퇴비화와 혐기성 소화가 있다. ${ }^{3,4)}$ 퇴비화의 경우 대량의 폐기물을 처리할 수 있다는 장점이 있지만, 넓은 부지가 필요하고 2-3개월 정도의 긴 처리 시간 이 소요된다는 단점 또한 존재한다. ${ }^{3)}$ 혐기성 소화의 경우 연속적인 처리가 가능하며, 처리 부산물로 발생하는 메탄 을 포집하여 자원화가 가능하다는 장점이 있다. ${ }^{5,6)}$ 하지만 초기 시설 투자 비용과 운전 비용이 높은 편이고 음식물 폐 기물 처리 후 발생하는 유출수 및 처리 부산물을 처리하는 
추가 과정이 필요하다.,7) 최근 산 발효 과정을 거친 음식물 폐기물을 이용한 뷰탄올의 생산에 대한 연구도 진행된 바 있다. ${ }^{8)}$

이러한 기술들과 더불어 최근에는 음식물 폐기물을 보다 친환경적으로 처리하기 위하여 다양한 곤충과 지렁이 등의 생물을 사용한 처리 기술이 활발히 연구되고 있다. 이러한 생물을 기반으로 한 음식물 폐기물의 처리는 설치 및 운영 비용이 낮고 그 처리 과정에서 메탄과 아산화질소 등의 온 실가스의 배출이 상대적으로 낮다는 장점이 존재한다. ${ }^{9)}$ 해 당 기술의 적용에는 곤충이 생존하고 번성할 수 있도록 온 도, 습도, 산도와 같은 환경 조건을 적절하게 유지하는 것이 중요하다. ${ }^{10,11)}$ 음식물 폐기물의 처리에 적용되는 동물의 대 표적인 종류로는 지렁이, 밀웜 등이 있다. 지렁이의 경우 처 리 과정에서 발생하는 병원체를 감소시키는 능력을 지니고 있으며, 밀웜의 경우 처리 후 가축의 사료로 활용 가능하다 는 장점이 있다. ${ }^{12}$

최근에는 여러 곤충 중 동애등에를 이용한 음식물 폐기물 처리 기술들도 활발히 연구되고 있다. ${ }^{13,14)}$ 동애등에의 경우 높은 수분과 온도 조건에서도 다양한 종류의 음식물 폐기물 을 처리할 수 있다고 보고되었다. ${ }^{12)}$ 동애등에 사육을 위한 환경 조건은 동아시아의 기후 조건과 유사해서 동애등에를 이용한 음식물 폐기물 처리 기술은 동아시아 지역에서 널리 이용될 수 있을 것으로 기대된다. ${ }^{14,15)}$ 이전 연구에 따르면, 100 마리의 동애등에 유충을 이용하여 $60 \mathrm{~g}$ 의 음식물 폐기 물을 처리한 경우 24 일의 처리 기간이 소요되었으며, 동애 등에를 이용해 음식물 폐기물을 처리하면 미생물 번식과 악 취 발생을 방지할 수 있다는 장점이 있다. ${ }^{13)}$ 음식물 폐기물 처리 완료 후 동애등에가 성충이 되기 전 번데기 단계에서 자원화 또한 가능한데 동애등에는 단백질과 지질 함량이 각 각 $40 \mathrm{wt} . \%$ 와 $30 \mathrm{wt} . \%$ 가량이어서 동물 사료 및 바이오디 젤의 원료로 활용 가능하다. ${ }^{15-17)}$ 따라서 동애등에는 음식물 폐기물 처리뿐 아니라 동물사료, 바이오연료, 화장품의 원 료 등으로도 이용 가능한 유용한 곤충자원으로 인식되고 있 고 농촌진흥청에서는 이와 같은 곤충자원을 기반으로 하는 산업 육성에 힘을 기울이고 있다. ${ }^{18)}$

동애등에를 이용한 음식물 폐기물의 효율적인 처리를 위 해서는 최적의 성장조건을 유지시키는 것이 중요한데 특히 배지의 구성성분은 동애등에의 크기, 성장률, 번식 등에 미 치는 영향이 크다. ${ }^{19)}$ 기존의 연구에서 사육 기질 내 단백질
과 지방의 비율이 $2.3: 1$ 일 때 동애등에 발달이 가장 빠르다 고 보고되었는데 ${ }^{20)}$ 음식물 폐기물의 발생 양상 및 성분을 분석했을 때 이러한 비율이 일관적으로 나타나기에는 어려 움이 있음을 알 수 있다. 또한 한국에서 발생하는 음식물 폐 기물을 동애등에의 배지로 이용할 경우, 문제를 야기하는 요소 중 하나는 $0.5 \sim 0.7 \%$ 가량의 높은 염분 농도이다. ${ }^{13,21)}$ 현재까지 배지의 구성 성분과 염분 농도가 동애등에의 성장 및 폐기물 처리 효율에 미치는 영향을 연구한 논문은 제한 적인데 동애등에를 이용한 음식물 폐기물 처리의 효율을 높 이고 동애등에를 유용한 자원으로 활용하기 위해서는 대량 생산에 적합한 음식물 폐기물에 기반한 배지의 제조에 관한 연구가 더 필요한 실정이다.

본 연구에서는 동애등에를 이용한 음식물 폐기물의 처리 에 적합한 배지를 개발하기 위해 음식물 폐기물에 콩나물 또는 밀기울 찌꺼기를 혼합하여 단백질과 지방의 비율과 염 분 농도를 조절하였다. 제조된 혼합 배지에서 동애등에를 배양하며 동애등에의 생장 및 배지 분해 양상을 분석하며 배지가 동애등에의 성장에 미치는 영향을 조사하였다. 단백 질과 지방의 비율은 기존의 연구 결과에 따라 동애등에의 성장이 빨리 이루어지는 것으로 알려진 2:1에 가까운 배합 이 되도록 음식물 폐기물에 콩나물과 밀기울을 추가하였 다. $^{20)}$ 닭 사료는 동애등에의 기호도에 맞는 사육 기질로써 단백질 함량이 높고 급여시 동애등에의 발달속도를 빠르게 하여 본 연구에서 대조구로 사용하였다. ${ }^{20)}$

\section{2. 실험방법}

\section{1. 배합배지의 제조}

배합 배지에 사용한 음식물 폐기물, 콩나물, 밀기울 찌꺼 기는 두채영농조합과 우리밀 가공공장영농법인에서 수거한 후 (주)평강비아이엠의 유용자원화장치(SP-PUW100, Pyeng Kang Bio It Mechatronics co., Ltd., Iksan, Korea)를 이용하 여 $55^{\circ} \mathrm{C}$ 에서 진공 저온 처리를 통해 가공하였다. 동애등에 사육 시 수분 함량은 $52-70 \mathrm{wt} . \%$ 가 최적이라고 알려져 있어 각 배지의 수분함량은 $60 \mathrm{wt} . \%$ 로 조정하였다. ${ }^{10)}$ Table 1은 실험에 사용한 각 배지의 약자와 배합비율 및 단백질과 지 방함량을 나타낸다. 음식물 폐기물+콩나물 배지는 4:6의 비 율로 배합하여 사용하였고 음식물 폐기물+밀기울 배지는 6:4로 배합하여 사용하였다.

Table 1. Characterization of rearing medium for BSFL. Error bars indicate one standard error of the mean $(n=3)$.

\begin{tabular}{ccccc} 
& Chicken feed & Food waste & $\begin{array}{c}\text { Food waste } \\
\text { + bean sprouts }\end{array}$ & $\begin{array}{c}\text { Food waste } \\
+ \text { wheat bran }\end{array}$ \\
Abbreviation & CF & FW & FW+BS & FW+WB \\
Protein:fat ratio & $2.8: 1$ & $1.6: 1$ & $2: 1$ & $2: 1$ \\
Mixing ratio (weight) & 1 & 1 & $2: 3$ & $3: 2$ \\
\hline
\end{tabular}




\section{2. 각 배지의 $\mathrm{pH}$ 및 염분농도}

2.1 에서 제조한 배합 배지 각각의 $\mathrm{pH}$ 와 염분농도를 측정 하였다. $\mathrm{pH}$ 는 토양오염공정시험기준 ES 07302.1에 따라 측 정하였다. ${ }^{22)}$ 각 배지의 염분농도 측정은 토양의 염분 측정 법에 따랐다. ${ }^{23}$ 각 배지와 증류수를 슬러리 형태로 섞어 하 루동안 방치한 후 슬러리를 원심분리하여 상등액을 염도측 정기(SB-2000 Pro, HM DIGITAL Inc, Seoul, Korea)를 이용 하여 측정하였다 $(n=3)$.

\section{3. 동애등에 유충의 사육}

3일 된 동애등에 유충을 (주)엔토모에서 구입하여 사용하 였다. 동애등에 유충의 사육을 위해 플라스틱 상자 내부에 2.1 에서 제조한 음식물 폐기물, 닭 사료, 음식물 폐기물+콩 나물, 음식물 폐기물+밀기울 배지 각각 $80 \mathrm{~g}$ 과 동애등에 유 충을 100 마리 투입한 후 아크릴로 제조한 사육장치 안에서 사육하였다 $(n=3)$. 사육 장치의 온도는 $30^{\circ} \mathrm{C}$ 로 유지하였다.

\section{4. 유충의 성장량, 발달속도, 생존율 및 배지 분해율 측정}

동애등에의 성장량 측정을 위해 각 사육 상자 속 동애등 에 유충 100 마리 중 10 마리를 임의로 선별하여 2 일 간격 으로 무게와 길이를 측정하였다. 성장량 측정을 마친 동애 등에 유충은 다시 사육 상자에 투입하였다. 동애등에 유충 의 길이를 측정하기 위해 ImageJ 소프트웨어(ImageJ $1.50 \mathrm{~b}$, Wayne Rasband, USA)를 사용하였다. 발달 속도의 경우 사 육 시작 후 각 배지에서 첫 번째 전용이 나오는 시기를 기 준으로 하여 측정하였으며 사육된 동애등에 유충의 생존율 은 아래 식에 따라 계산하였다.

$$
\begin{aligned}
& \begin{array}{c}
\text { 동애등에 유충의 } \\
\text { 생존율 }(\%)
\end{array}=\frac{\text { 생존한 유충의 마리 수 }}{\text { 사육에 사용한 }} \times 100 \\
& \text { 동애등에 마리 수 }
\end{aligned}
$$

실험 종료 후 배지 분해율은 아래의 식에 따라 계산하였다.

배지 분해율 $(\%)=\frac{W_{1}-W_{2}}{W_{1}} \times 100$

$W_{1}$ : 실험에 투입한 배지의 양

$W_{2}$ : 실험 종료 후 남은 배지의 양

각 배지에서 자란 동애등에의 성장률은 아래의 식에 따라 계산하였다.

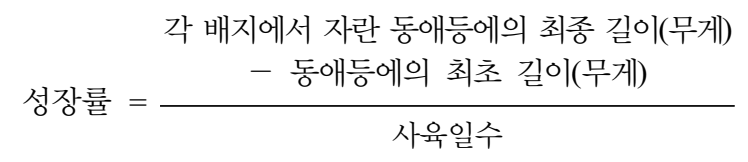

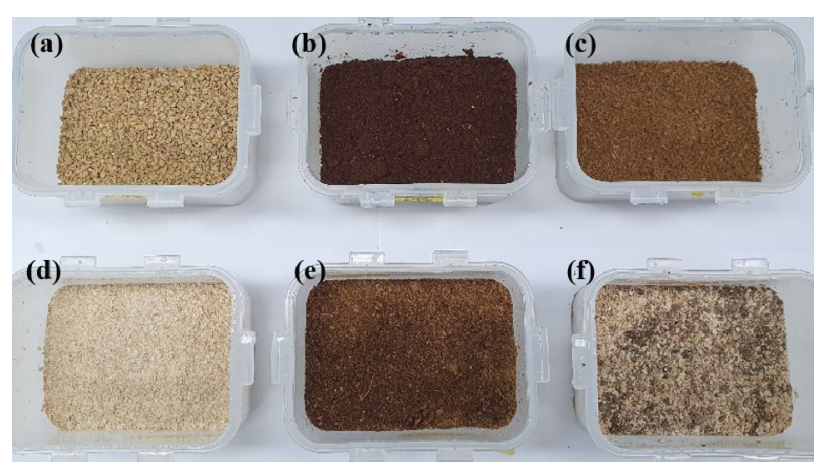

Fig. 1. Rearing medium used for the experiment. (a) Chicken feed; (b) food waste; (c) bean sprouts; (d) wheat bran; (e) food waste + bean sprouts; (f) food waste + wheat bran.

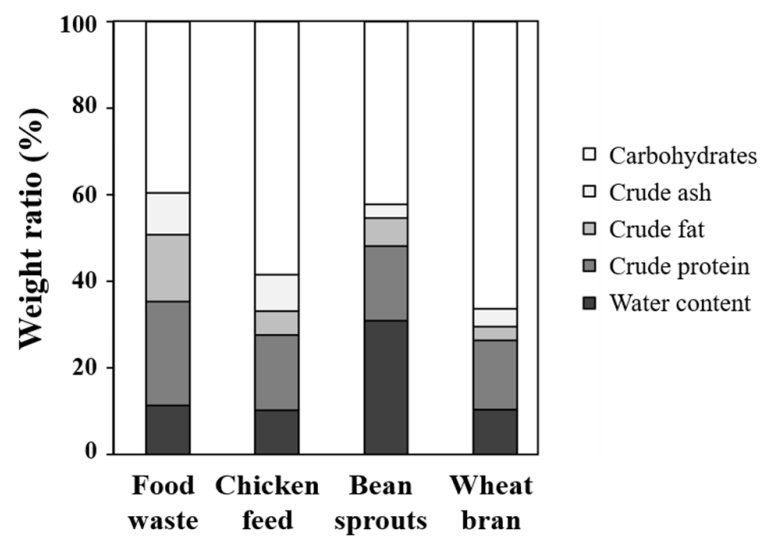

Fig. 2. Composition of substrates (weight ratio (\%)) used for media $(n=2)$.

\section{5. 통계 분석}

본 실험에서 얻어진 결과들은 SAS package (SAS Institute, 2000)의 ANOVA test로 분석되었고 처리 간 유의성 검정을 위해 Tukey's range test를 이용하여 $95 \%$ 수준에서 유의성 분석 을 실시하였다.

\section{3. 결과 및 고찰}

\section{1. 각 배지의 특성 분석}

Fig. 1은 본 실험에서 사용한 유용자원화장치를 이용하여 건조 전처리 과정을 통해 생산된 분말 형태의 음식물 폐기 물을 나타낸다. 닭사료와 밀기울은 전처리하지 않고 사용하 였으며 닭사료의 경우 노란색의 알갱이 형태였다. 음식물 폐기물은 암갈색의 고운 가루 형태였으며 콩나물과 밀기울 도 각각 갈색과 흰색의 가루로 사용하였다.

각 배지의 구성 성분 분석에 대한 결과는 Fig. 2에 나타나 있다. 탄수화물, 지방, 단백질이 주된 구성 물질이며 배지의 종류에 따라 그 비율은 서로 다르게 나타났다. 기존의 연구 에 의하면 단백질 함량이 $20 \mathrm{wt.} \%$ 이상을 차지할 때 고단백 

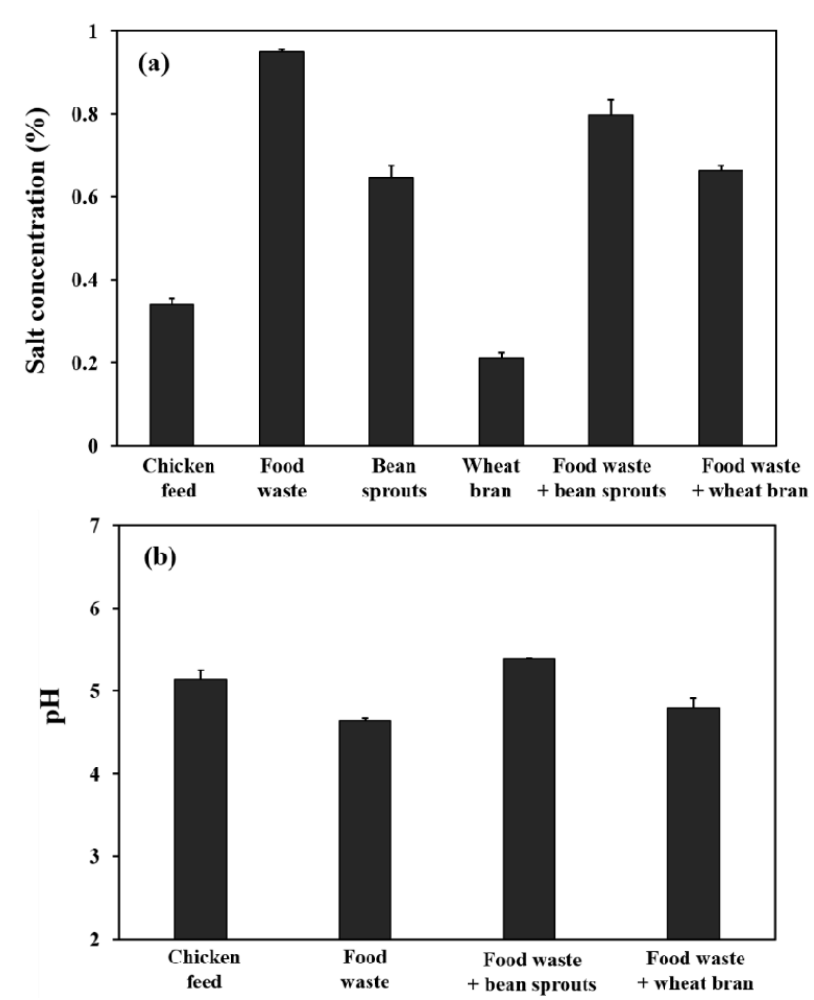

Fig. 3. Characteristics of each medium. Error bars indicate one standard error of the mean $(n=3)$.

으로 분류할 수 있으며, $15 \mathrm{wt.} \%$ 이하의 함량을 저단백으로 분류 가능하다. ${ }^{20)}$ 본 실험에 사용된 배지 중 음식물 폐기물 에서 24 wt.\%로 가장 높은 단백질 함량을 보였으며, 닭사 료, 콩나물, 밀기울에서 각각 $17,17,16 \mathrm{wt} \%$ 로 유사한 단 백질 함량을 보였다. 이와 더불어 유용자원화장치를 통해 처리한 음식물 폐기물에서 지방의 비율이 약 $15 \mathrm{wt} . \%$ 로 높 은 함량으로 나타났다. ${ }^{20)}$

Fig. 3은 실험에 사용한 각 배지의 $\mathrm{pH}$ 와 염분 농도를 나타 낸다. 닭 사료, 음식물 폐기물, 음식물 폐기물+콩나물 그리고 음식물 폐기물+밀기울 각각의 $\mathrm{pH}$ 는 5.14, 4.64, 5.39 그리고 4.80 으로 확인되었다. 각 배지의 염도는 닭 사료 $0.34 \%$, 음식 물 폐기물 $0.95 \%$, 음식물 폐기물+콩나물 $0.80 \%$, 그리고 음 식물 폐기물+밀기울 $0.66 \%$ 로 닭 사료에서 가장 낮았으며 음 식물 폐기물에 콩나물과 밀기울을 배합하였을 때 염분농도 가 감소하는 것을 확인할 수 있었다. 또한 콩나물과 밀기울 만의 염분농도는 각각 $0.64 \%$ 그리고 $0.19 \%$ 였다. 이전 연구 결과에 따르면, 폐기물의 초기 $\mathrm{pH}$ 가 4 이하일 경우 동애등에 성장에 부정적인 영향을 미친다고 보고되었다. ${ }^{24)}$ 본 연구에 서의 $\mathrm{pH}$ 측정 결과는 음식물 폐기물에서 가장 낮았고, 콩나 물 또는 밀기울을 혼합하였을 때, $\mathrm{pH}$ 가 높아지는 것으로 나 타났다. 염분 농도와 더불어 $\mathrm{pH}$ 또한 동애등에의 성장에 영 향을 미치는 요소로 작용할 수 있지만, 이전 연구에서 부정 적인 영향을 나타낸 결과인 $\mathrm{pH} 4$ 보다 높은 수치를 나타내었 고, 배지 간 $\mathrm{pH}$ 의 차이가 크지 않았기 때문에 $\mathrm{pH}$ 에 따른 생
장 차이는 크지 않았을 것으로 예상된다.

본 연구에서 사용된 음식물 폐기물의 염분 농도의 경우 이전 연구에서 제시한 일반적인 음식물 폐기물의 염분 농도 인 $0.5 \sim 0.7 \%$ 보다 높은 $0.95 \%$ 였다. ${ }^{13,21,25)}$ 음식물 폐기물의 염분 농도의 경우 그 배출원에 따라 더 높거나 낮은 수치를 나타낼 수 있을 것으로 사료된다. 이전 연구 결과에 따르면 인위적으로 $1,2,3 \%$ 로 염분 농도를 조절한 음식물 폐기물 중 $1 \%$ 이상의 염분 농도는 성장률에 부정적인 영향을 미친 것으로 보고되었다. ${ }^{13)}$ 또한 0.5 에서 $5 \%$ 사이의 염분 농도에 대한 동애등에의 성장률 영향을 분석한 결과 $1 \%$ 이상의 농 도에서 성장이 감소하는 경향이 나타났다. ${ }^{21)}$ 따라서 각 연 구에서 적용한 성장 조건과 음식물 폐기물의 성상 차이를 고려하여 종합적으로 살펴보았을 때, $1 \%$ 이상의 염분 농도 에서 동애등에 성장의 저해가 나타나는 것으로 판단된다.

\section{2. 유충의 성장량과 발달속도}

Fig. 4는 각 배지에서 자란 동애등에를 관찰한 모습을 나 타내었다. Fig.5는 각 배지에서 자란 동애등에 유충의 무게 와 길이를 나타낸다. 처리한 음식물 폐기물을 기반으로 한 다양한 배지에서 키운 동애등에의 무게를 측정한 결과 1 일 차에는 각 배지에서 자란 동애등에 유충의 무게가 $0.01 \mathrm{~g}$ 으 로 배지에 따른 차이를 보이지 않았다(Fig.5(a)). 3 일차에는 닭 사료, 음식물 폐기물, 음식물 폐기물+콩나물 그리고 음 식물 폐기물+밀기울 배지에서 자란 동애등에 유충의 무게 가 각각 $0.05 \mathrm{~g}, 0.02 \mathrm{~g}, 0.02 \mathrm{~g}$ 그리고 $0.04 \mathrm{~g}$ 으로 닭 사료에 서 자란 동애등에 유충이 무게가 가장 높았고 음식물 폐기 물에서 자란 동애등에 유충의 무게가 가장 낮았다. 5 일차에 는 닭 사료, 음식물 폐기물, 음식물 폐기물+콩나물 그리고 음식물 폐기물+밀기울 배지에서 자란 동애등에 유충의 무 게는 각각 $0.14 \mathrm{~g}, 0.05 \mathrm{~g}, 0.10 \mathrm{~g}$ 그리고 $0.13 \mathrm{~g}$ 으로 나타났 다. 3 일차와 마찬가지로 닭 사료에서 자란 동애등에 유충이 최고의 무게를 보였고 음식물 폐기물에서 자란 동애등에 유

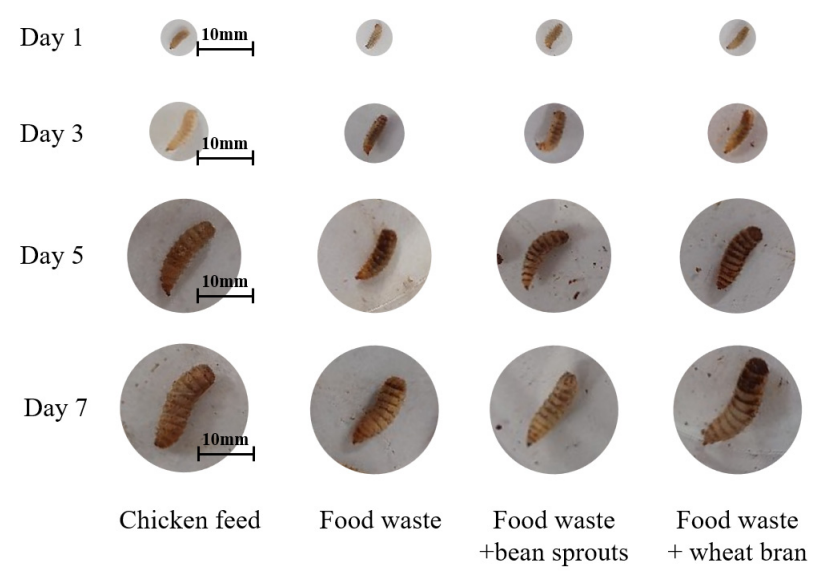

Fig. 4. Photographs showing the development of BSFL reared on diverse media during the experimental period. 

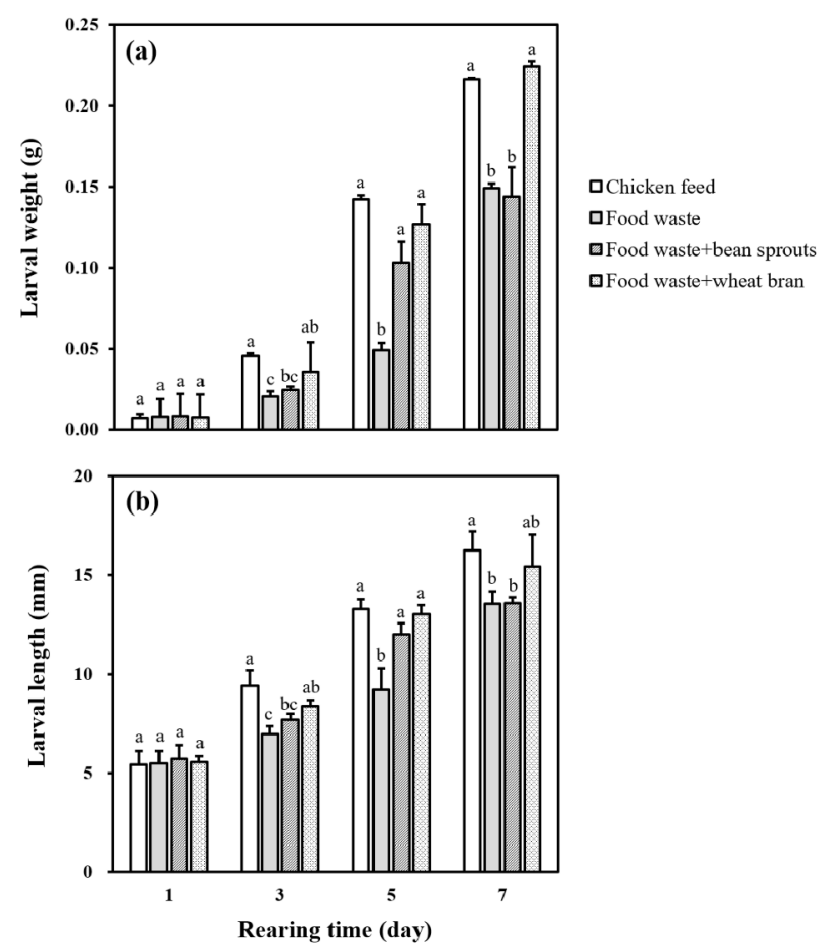

Fig.5. Weight and length of black soldier fly larvae reared on each medium. Error bars indicate one standard error of the mean $(n=3)$.

충이 최저의 무게를 보였다. 7일차에는 닭 사료, 음식물 폐 기물, 음식물 폐기물+콩나물 그리고 음식물 폐기물+밀기울 배지에서 자란 동애등에 유충의 무게가 각각 $0.22 \mathrm{~g}, 0.15 \mathrm{~g}$, $0.14 \mathrm{~g}$ 그리고 $0.22 \mathrm{~g}$ 으로 닭사료와 음식물 폐기물+밀기울 배지에서 자란 동애등에 유충이 가장 무거웠다(Fig.5(a)).

각 배지에서 자란 동애등에의 길이와 무게는 1 일차에는 실험군별로 차이가 없었다(Fig.5). 3일차에 무게와 길이는 닭사료에서 가장 높았고 그 다음으로 음식물 폐기물+밀기 울 배지에서 높았다. 5 일차에는 음식물 폐기물 배지를 제외 하고 모든 배지에서 자란 동애등에의 길이와 무게가 통계적 으로 차이가 없었다. 7일차에는 닭사료와 음식물 폐기물+밀 기울에서 자란 동애등에의 길이와 무게가 가장 높은 경향을 보였다. 측정 일자에 관계없이 음식물 폐기물+밀기울 배지 에서 자란 동애등에 유충이 대조구로 사용된 닭 사료 배지 에서 자란 동애등에 유충과 비슷한 무게와 길이를 보이며 동애등에 사육용 실용화 배지로 쓰일 수 있는 가능성을 제 시하였다. 반면 음식물 폐기물 배지에서 자란 동애등에 유 충의 길이와 무게가 다른 배지에서 자란 동애등에 유충에 비해 저조한 이유는 높은 염분 농도와 영양소의 불균형에 의한 것으로 보인다.

본 연구에서 음식물 폐기물의 염분 농도는 $0.95 \%$ 로 나타났 으며 이는 선행연구에서 동애등에의 성장률에 영향을 줄 수 있다고 알려진 염분농도 $1 \%$ 에 가까운 수치이다. ${ }^{13)}$ Oonincx et al. (2015)는 사육 기질 내 단백질과 지방의 비율이 2.3:1일
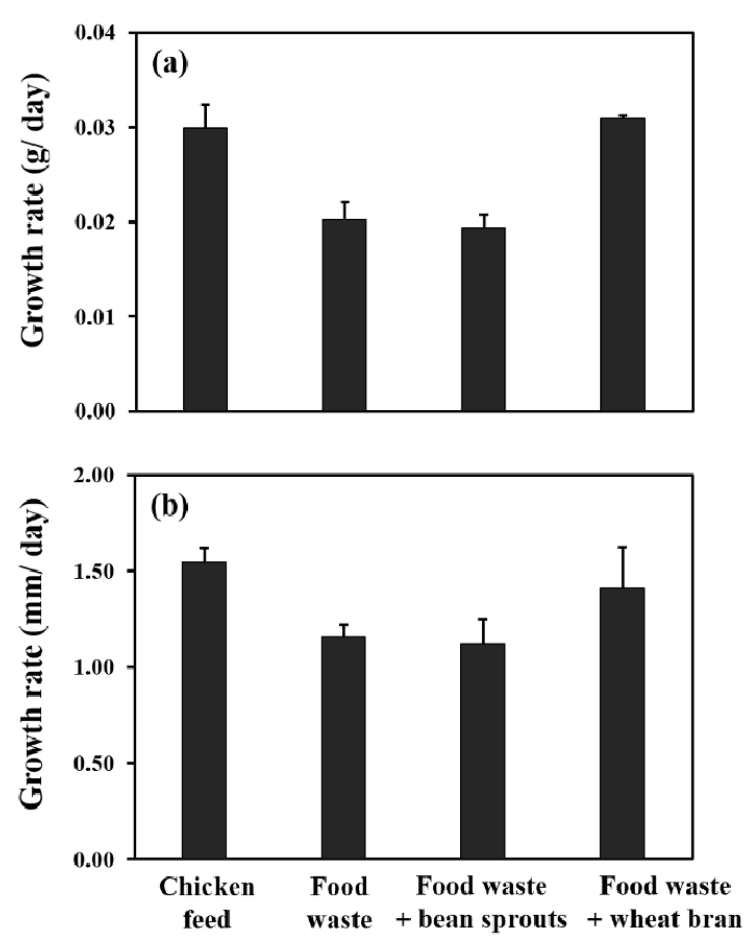

Fig.6. Growth rate of black soldier fly larvae reared on each medium. Error bars indicate one standard error of the mean $(n=3)$.

때 동애등에 발달이 가장 빠르다고 보고하였다. ${ }^{20)}$ 이를 감안 하여 음식물 폐기물+콩나물 그리고 음식물 폐기물+밀기울 배합 배지의 경우 단백질: 지방의 비율을 $2: 1$ 에 가깝게 제조 한 반면 음식물 폐기물 배지는 그 비율이 1.6:1에 가까웠다. 단백질: 지방의 비율은 낮았지만 Fig.2에서 볼 수 있듯이 음 식물 폐기물의 단백질 함량 자체는 $24 \%$ 로 다른 성분들에 비 해 높았다. 선행연구 결과 기질의 단백질 함량이 동애등에의 발달에 큰 영향을 미친다고 보고하였다. ${ }^{20)}$ 하지만 기질 내에 포함된 필요 이상의 단백질함량은 생존율을 감소시키는 등 동애등에 발달에 부정적인 영향을 미친다고 보고되었다. ${ }^{26)}$ 이러한 결과와 마찬가지로 본 연구에서도 다른 배지에 비해 상대적으로 높은 단백질 함량으로 인해 동애등에의 성장이 영향을 받았을 가능성이 존재한다. 음식물 폐기물+밀기울 배 합 배지에서 자란 동애등에 유충의 길이와 무게가 높았던 또 다른 이유는 밀기울의 첨가로 인한 염분농도의 감소가 동애 등에의 발달에 긍정적인 영향을 미친 것으로 생각할 수 있다. 이전의 연구에서 염분농도 $1 \%$ 에서 동애등에의 성장률이 영 향을 받을 수 있다고 보고되었는데 ${ }^{13)}$ 본 연구에서 음식물 폐 기물에 밀기울을 추가하였을 때 염분농도가 $0.95 \%$ 에서 $0.66 \%$ 로 감소한 것으로 보아 동애등에가 염분농도에 영향을 받지 않고 생장한 것으로 보인다.

Fig. 6은 각 배지에서 자란 동애등에의 성장률을 나타낸 다. 각 배지에서 자란 동애등에의 성장률은 무게와 길이 각 각 $0.03 \mathrm{~g} / \mathrm{day}$ 와 $1.55 \mathrm{~mm} / \mathrm{day}$ 로 닭사료에서 가장 높았으며 

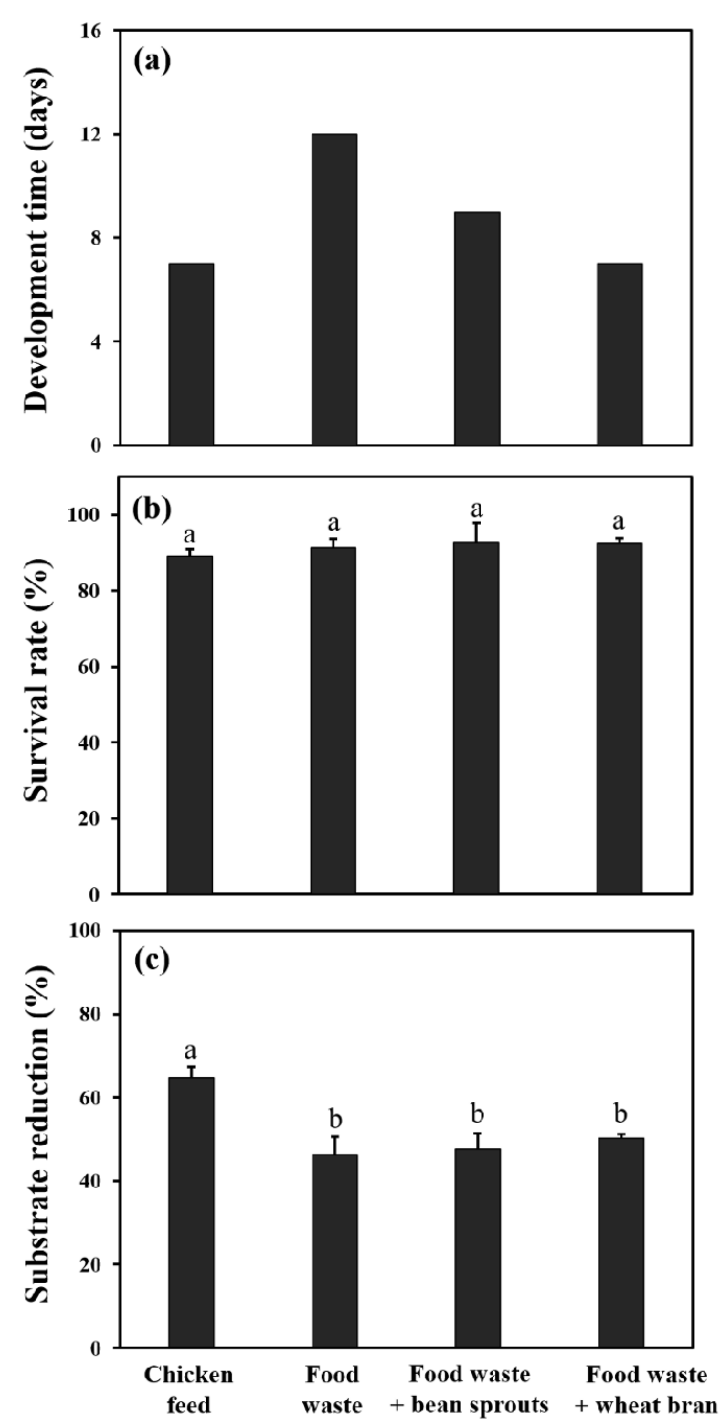

Fig. 7. Development time into first prepupae (a), survival rate (b), and substrate reduction rate (c) of $H$. illucens reared on each medium. Error bars indicate one standard error of the mean $(n=3)$.

그 다음으로는 음식물 폐기물+밀기울 배지에서 자란 동애 등에의 성장률이 높았다. 기존의 연구에서 밀 부산물, 맥주 양조 부산물, 돼지 분뇨, 풀에서 자란 동애등에의 성장률을 조사하였다. ${ }^{27)}$ 연구결과 밀부산물에서 자란 동애등에의 성 장률이 $2.80 \mathrm{mg} / \mathrm{day}$ 로 가장 높았다. 또 다른 연구에서도 야 채와 과일 혼합물, 과일 찌꺼기, 양조장 부산물에서 자란 동 애등에의 성장률을 조사하였다. ${ }^{28)}$ 연구결과 맥주 양조 부산 물에서 자란 동애등에의 성장률이 $0.014 \mathrm{~g} / \mathrm{day}$ 를 보이며 가 장 높게 나타났다. 이와 비교하여 우리의 연구에서 닭사료 와 음식물 폐기물+밀기울 배지에서 자란 동애등에의 성장 률은 $0.03 \mathrm{~g} / \mathrm{day}$ 로 높은 성장률을 보였다. 이는 음식물 폐기 물+밀기울 배지가 동애등에의 성장을 촉진시키는 배지로 쓰일 수 있다는 것을 의미한다.

Fig. 7은 각 배지에서 자란 동애등에의 발달속도와 생존율
그리고 배지 분해율을 나타낸다. 각 배지에서 자란 동애등 에의 첫 번째 전용, 즉 애벌레에서 번데기가 되기 직전의 상 태가 되기까지의 발달 속도는 닭 사료와 음식물 폐기물+밀 기울 배합 배지에서 자란 동애등에 유충의 경우 7일로 측정 되었고, 음식물 폐기물+콩나물 배합 배지의 경우 9 일 그리 고 음식물 폐기물 배지에서 자란 동애등에 유충의 경우 12 일이 걸렸다(Fig.7(a)). 닭 사료와 음식물 폐기물+밀기울 배 합 배지에서 자란 동애등에 유충의 발달 속도가 빠른 것은 밀기울에 대한 동애등에 유충의 선호도와 더불어 염분 농도 의 감소에 의한 것으로 사료된다. 닭 사료와 음식물 폐기물 +밀기울 배합 배지 모두 밀기울을 포함하고 있는데 밀기울 의 성분이 동애등에의 발달에 도움을 주는 것으로 사료된 다. 이전 연구에서는 음식물 폐기물과 닭 사료에서 자란 동 애등에 유충의 발달 속도를 조사하였다. ${ }^{14)}$ 연구결과 닭 사 료와 음식물 폐기물에서 자란 동애등에 유충의 발달 속도는 14 일이었다. 같은 기질을 사용했음에도 불구하고 우리의 연 구에서 동애등에 유충의 발달 속도가 더 빠르게 관찰된 것 은 사육 장소나 온도, 습도 등 실험 조건의 차이에서 비롯됐 음을 유추할 수 있다.

\section{3. 동애등에 유충의 생존율 및 배지 분해율 측정}

닭 사료, 음식물 폐기물, 음식물 폐기물+콩나물 그리고 음 식물 폐기물+밀기울 배지에서 자란 동애등에 유충의 생존율 은 각각 $89 \%, 91 \%, 93 \%$ 그리고 $92 \%$ 로 통계적으로 유의한 차이가 없었다 $(P>0.05)$ (Fig. 7(b)). 이러한 결과로 볼 때 각 배지의 염분농도나 $\mathrm{pH}$ 의 차이는 동애등에 유충의 생존율에 영향을 미치지 않는 것으로 보인다. 기존의 연구에서는 음 식물 폐기물 내 염도가 $0.5 \sim 1.3 \%$ 의 범위에서는 동애등에의 성장이 영향을 받지 않고 잘 자란다고 보고되었다. ${ }^{21)}$ 또 다 른 연구에서도 동애등에 유충이 음식물 폐기물을 분해할 때 $3 \%$ 의 염분 농도에서도 동애등에의 생존율이 영향을 받지 않았지만 성장률에는 영향을 받았다. ${ }^{13)}$ 본 논문의 결과도 이 와 유사하게 생존율에는 큰 영향을 주지 않았다. 하지만 배 지의 염분농도에 따라 동애등에의 무게 및 길이에 차이가 나타났으며, 이는 배지의 염분농도가 동애등에의 발달상태 에 영향을 미친다는 것으로 해석할 수 있다. 본 연구결과와 마찬가지로 선행연구에서도 방앗간 부산물, 사람의 대변, 가 금류 도축장 폐기물, 소의 분변, 구내식당 폐기물 그리고 채 소 찌꺼기에서 자란 동애등에의 생존율은 90 99\%로 사용한 기질에 따라 유의한 차이가 없는 것으로 보고되었다. ${ }^{29)}$ 이는 동애등에가 기질의 종류에 관계없이 다양한 기질을 분해하 며 생장할 수 있다는 것을 의미한다. ${ }^{29)}$ 배지 분해율의 경우 닭 사료, 음식물 폐기물, 음식물 폐기물+콩나물 그리고 음식 물 폐기물+밀기울 배지에서 각각 $65 \%, 46 \%, 48 \%$ 그리고 $50 \%$ 로 동애등에 유충이 닭 사료를 제일 잘 분해하는 것을 알 수 있었다(Fig.7(c)). 이전 연구에서 음식물 폐기물을 기 
질로 자란 동애등에의 배지분해율은 $81.8 \%$ 로 우리의 연구 에서의 배지 분해율보다 높았다. ${ }^{30)}$ 또 다른 연구에서도 동 애등에에 의한 음식물 폐기물의 분해율은 $55.3 \%$ 로 우리의 연구와 비교하여 높은 수치를 보였다. ${ }^{14)}$ 이는 음식물마다 다양한 성상을 가지므로 그 구성에 있어 차이가 나며 이러 한 차이가 동애등에의 분해율에도 영향을 미친 것으로 사료 된다.

\section{4. 결 론}

본 연구에서는 음식물 폐기물 처리와 동애등에 사육을 위 해 음식물 폐기물에 콩나물과 밀기울 찌꺼기를 추가한 혼합 배지를 만들어서 단백질과 지방의 비율을 조정하고 이와 같 은 배지가 동애등에 사육에 적합한지 배양 실험을 통해 분 석하였다. 닭 사료, 음식물 폐기물, 음식물 폐기물+콩나물 그리고 음식물 폐기물+밀기울 배지에서 동애등에를 사육한 결과 닭 사료와 음식물 폐기물+밀기울에서 자란 동애등에 의 성장률과 발달 속도가 가장 높았다. 동애등에의 생존율 은 모든 배지에서 $89 \%$ 이상으로 배지의 종류에 따른 유의 한 차이가 없었다. 음식물 폐기물을 단독으로 배지로 사용 했을 때는 콩나물과 밀기울 찌꺼기를 배합했을 때에 비해 동애등에의 성장률과 발달 속도가 낮았는데 이와 같은 결과 로 보았을 때 음식물 폐기물을 동애등에 대량 사육의 배지 로 이용할 때 밀기울과 콩나물 등의 농업부산물을 사용해 단백질과 지방의 비율을 조정하고 염분을 낮출 필요가 있는 것으로 사료된다. 실제 공정에 이를 적용할 경우 음식물 폐 기물의 배출원에 따른 성상 차이를 고려한 농업부산물의 혼 합 배율 조절을 통해 일정한 성상을 유지하고 동애등에 성 장 효율을 극대화하는 과정이 요구될 것으로 예상된다. 본 연구에 적용된 유용자원화장치를 이용한 전처리 과정을 통 해 초기의 불규칙한 음식물 폐기물의 균질화 및 수분 함량 조절이 가능하며, 주기적인 단백질과 지질 함량 분석을 통 한 균형적인 공정 운전이 가능할 것으로 예상된다. 따라서 음식물 폐기물을 처리하는 동시에 동애등에와 같은 유용 곤 충을 대량으로 사육하는 데 필요한 효율적인 음식물 폐기물 에 기반한 배지를 개발하기 위해서는 음식물 폐기물에 더 다양한 농업부산물을 추가하여 영양분의 조성을 조절하여 동애등에의 생장 양상을 분석하는 연구가 추가적으로 필요 하다.

\section{Acknowledgement}

본 결과물은 환경부의 재원으로 한국환경산업기술원의 환경정책기반공공기술개발사업의 지원을 받아 연구되었습 니다(2018000710002). 이에 감사드립니다.

\section{References}

1. Ministry of Environment, Tongyeong city ordinance on food waste generation control, collection, transportation, and recycling No. 1528(2020).

2. W. Nichols, N. Smith, Waste Generation and Recycling Indices 2019 Overview and findings, https://www.circularonline.co. uk/wpcontent/uploads/2019/07/Verisk_Maplecroft_Waste_Ge neration_Index_Overview_2019.pdf, June(2019).

3. J. W. Levis, M. A. Barlaz, N. J. Themelis, P. Ulloa, Assessment of the state of food waste treatment in the United States and Canada, Waste Manage., 30(8-9), 1486-1494(2010).

4. C. S. K. Lin, L. A. Pfaltzgraff, L. Herrero-Davila, E. B. Mubofu, S. Abderrahim, J. H. Clark, A. A. Koutinas, N. Kopsahelis, K. Stamatelatou, F. Dickson, S. Thankappan, Z. Mohamed, R. Brocklesby, R. Luque, Food waste as a valuable resource for the production of chemicals, materials and fuels: Current situation and global perspective, Energy Environ: Sci., 6(2), 426-464(2013).

5. R. Zhang, H. M. El-Mashad, K. Hartman, F. Wang, G. Liu, C. Choate, P. Gamble, Characterization of food waste as feedstock for anaerobic digestion, Bioresour. Technol., 98(4), 929-935(2007).

6. M. J. Park, G. T. Seo, A study on membrane filtration characteristics of methanogenic mixed liquor in two phase anaerobic digestion of food waste, J. Korean Soc. Environ. Eng., 42(3), 151-163(2020).

7. C. J. Jeong, S. Park, H. Song, High-graded characteristics of solid refuse using food waste fermentation product, J. Korean Soc. Environ. Eng., 40(9), 372-377(2018).

8. D. G. Lee, J. J. Yoon, Biobutanol production from acid fermented solution of food waste using Clostridium sp., J. Korean Soc. Environ. Eng., 40(5), 211-216(2018).

9. W. Pang, D. Hou, J. Chen, E. E. Nowar, Z. Li, R. Hu, J. K. Tomberlin, Z. Yu, Q. Li, S. Wang, Reducing greenhouse gas emissions and enhancing carbon and nitrogen conversion in food wastes by the black soldier fly, J. Environ. Manage., 260, 110066(2020).

10. K. B. Barragan-Fonseca, M. Dicke, J. J. A. van Loon, Nutritional value of the black soldier fly (Hermetia illucens L.) and its suitability as animal feed-a review, J. Insects Food Feed., 3(2), 105-120(2017).

11. M. Shumo, F. M. Khamis, C. M. Tanga, K. K. M. Fiaboe, S. Subramanian, S. Ekesi, A. van Huis, C. Borgemeister, Influence of temperature on selected life-history traits of black soldier fly (Hermetia illucens) reared on two common urban organic waste streams in Kenya, Animals, 9(3), 79(2019).

12. T. M. Fowles, C. Nansen, Insect-based bioconversion: value from food waste, Food Waste Management, E. Närvänen, N. Mesiranta, M. Mattila, A. Heikkinen (Eds), Palgrave Macmillan, Cham, pp. 321-346(2020).

13. S. Cho, C. H. Kim, M. J. Kim, H. Chung, Effects of microplastics and salinity on food waste processing by black 
soldier fly (Hermetia illucens) larvae, J. Ecology Environ., 44, 1-9(2020).

14. C. Lalander, S. Diener, C. Zurbrügg, B. Vinnerås, Effects of feedstock on larval development and process efficiency in waste treatment with black soldier fly (Hermetia illucens), J. Cleaner Prod., 208, 211-219(2019).

15. A. Singh, K. Kumari, An inclusive approach for organic waste treatment and valorisation using black soldier fly larvae: a review, J. Environ. Manage., 251, 109569(2019).

16. V. C. Cummins Jr, S. D. Rawles, K. R. Thompson, A. Velasquez, Y. Kobayashi, J. Hager, C. D. Webster, Evaluation of black soldier fly (Hermetia illucens) larvae meal as partial or total replacement of marine fish meal in practical diets for Pacific white shrimp (Litopenaeus vannamei), Aquaculture., 473, 337-344(2017).

17. S. St Hilaire, C. Sheppard, J. K. Tomberlin, S. Irving, L. Newton, M. A. McGuire, E. E. Mosley, R. W. Hardy, W. Sealey, Fly prepupae as a feedstuff for rainbow trout, Oncorhynchus mykiss, J. World. Aquacult. Soc., 38(1), 59-67(2007).

18. Rural Development Administration Home Page, http://www.rda. go.kr, July(2020).

19. T. T. X. Nguyen, J. K. Tomberlin, S. Vanlaerhoven, Influence of resources on Hermetia illucens (Diptera: Stratiomyidae) larval development, J. Med. Entomol., 50(4), 898-906(2013).

20. D. G. Oonincx, S. Van Broekhoven, A. Van Huis, J. J. van Loon, Feed conversion, survival and development, and composition of four insect species on diets composed of food by-products, PLoS One, 10(12), e0144601(2015).

21. J. H. Kwon, J. Y. Kim, Treatment efficiency of food waste by the black soldier fly (Hermetia illucens) depending on salinity and moisture contents, J. Korea Soc. Waste Manag., 33(6), 590-597(2016).

22. Ministry of Environment, Soil pollution process test standard, Ministry of Environment notice No. 2015-261.

23. M. Hardie, R. Doyle, Measuring soil salinity, plant salt tolerance, M. Hardie, R. Doyle (Eds), Humana Press, Totowa, NJ. pp. 415-425(2012).

24. J. Ma, Y. Lei, K. Rehman, Z. Yu, J. Zhang, W. Li, Q. Li, J. K. Tomberlin, L. Zheng, Dynamic effects of initial $\mathrm{pH}$ of substrate on biological growth and metamorphosis of black soldier fly (Diptera: Stratiomyidae), Environ. Entomol., 47(1), 159-165(2018).

25. L. Guo, Y. Zong, M. Lu, J. Zhang, Effect of different substrate concentrations and salinity on hydrogen production from mariculture organic waste (MOW), Int. J. Hydrogen Energy, 39(2), 736-743(2014).

26. M. Tschirner, A. Simon, Influence of different growing substrates and processing on the nutrient composition of black soldier fly larvae destined for animal feed, J. Insects as Food Feed., 1(4), 249-259(2015).

27. Z. Liu, M. Minor, P. C. Morel, A. J. Najar-Rodriguez, Bioconversion of three organic wastes by black soldier fly (Diptera: Stratiomyidae) larvae, Environ. Entomol., 47(6), 1609-1617(2018).

28. M. Meneguz, A. Schiavone, F. Gai, A. Dama, C. Lussiana, M. Renna, L. Gasco, Effect of rearing substrate on growth performance, waste reduction efficiency and chemical composition of black soldier fly (Hermetia illucens) larvae, J. Sci. Food Agric., 98(15), 5776-5784(2018).

29. M. Gold, C. M. Cassar, C. Zurbrügg, M. Kreuzer, S. Boulos, S. Diener, A. Mathys, Biowaste treatment with black soldier fly larvae: increasing performance through the formulation of biowastes based on protein and carbohydrates, Waste Manage., 102, 319-329(2020).

30. E. M. Nyakeri, H. J. O. Ogola, M. A. Ayieko, F. A. Amimo, Valorisation of organic waste material: growth performance of wild black soldier fly larvae (Hermetia illucens) reared on different organic wastes, J. Insects as Food Feed., 3(3), 193-202(2017).

\section{Authors}

\section{Chul-Hwan Kim}

Department of Environmental Engineering, Konkuk University, Researcher, ORCID(10 0000-0001-8737-2787

\section{Kwanyoung Ko}

Department of Environmental Engineering, Konkuk University, Researcher, ORCID( 00000-0002-5320-9348

\section{Jongkeun Lee}

Department of Civil \& Environmental Engineering, Konkuk University, Research Professor, ORCID(1) 0000-0002-7624-4066

\section{Haegeun Chung}

Department of Environmental Engineering, Konkuk University, Professor, ORCID (D) 0000-0001-6260-6233 